\title{
The scope of school autonomy in practice: An empirically based classification of school interventions
}

\section{Annemarie Neeleman ${ }^{1}$}

Published online: 24 August 2018

(C) The Author(s) 2018

\begin{abstract}
In many countries, education systems are moving towards a combination of increased school autonomy and intensified accountability. In the wake of that shift, decision-making at the school level has become paramount, and the role of the school leader has gained in importance. Despite these trends, surprisingly little is known about how schools and school leaders use school autonomy in practice. To study the use of school autonomy in practice internationally, and, subsequently, its impact on outcomes, a classification is needed to capture the full range of school interventions. An extensive literature review revealed that existing classifications are inadequate for these purposes. This article presents the mixed-methods construction and validation of an empirically based classification of school interventions that allows for the identification, analysis, and comparison of the actual use of school autonomy. To capture the range of school autonomy in practice, a school intervention was broadly defined as a planned action intended to cause change in the school. That definition was not confined to innovative interventions and did not rule out any school decision-making areas. An open-response questionnaire was employed for the same purpose. Because of the high level of school autonomy in the Dutch education system, the study was carried out among secondary-education school leaders in the Netherlands. School leaders with the ultimate process responsibility for their school were regarded as decision-making executives at the school level. To ensure the face and content validation of the classification, school-level decision-making representatives were actively involved at all stages of the process.
\end{abstract}

Keywords School autonomy $\cdot$ School interventions · Decision-making · Classification $\cdot$ School change $\cdot$ School leaders

Annemarie Neeleman

mbmneeleman@gmail.com

1 Maastricht University, Maastricht, The Netherlands 


\section{Introduction}

During the last decades, countries all over the world have geared their education systems along the path of increasing school autonomy alongside more rigorous accountability (Cheng et al. 2016; OECD 2012). While debates on educational governance push ideas on autonomy and accountability forward (Theisens et al. 2017), large-scale international comparative studies are used as support (OECD 2011). Mainly based on OECD PISA-data, researchers conclude that education systems perform better if schools can decide which textbooks they want to use, which teachers they want to hire, and how they spend their budgets. School autonomy only leads to better performance, however, in systems with rigorous accountability (Fuchs and Woessmann 2007).

The concept of school autonomy requires specification, as differences between countries are substantial (OECD 2011, 2012). While Shanghai-China combines high levels of school autonomy in the area of resource allocation with low levels of autonomy in the area of curricula and assessment, the exact opposite is the case in Korea and New Zealand. In the Netherlands, schools have high levels of autonomy when it comes to hiring and firing of teachers while schools in Greece and Italy have no such authority. Such specification is all the more important as school autonomy plays out differently for developing and developed countries (Hanushek et al. 2013) and particular combinations of autonomy and accountability may either exacerbate or diminish equity in education (Werfhorst and Mijs 2010). Testifying to this much debated issue, is the fact that policies are vastly different. While schools in Poland have seen their levels of autonomy in resource allocation decrease quite dramatically between 2000 and 2009, schools in Italy were granted much more autonomy during those years (Hanushek et al. 2013).

The concept of school autonomy also requires qualification. Research makes very clear that policies to enhance school autonomy do not necessarily lead to autonomy in practice. The key question is whether and how autonomy opportunities are enacted in schools, particularly by school principals (Agasisti et al. 2013; Ball et al. 2012; Shirley 2016). As yet, surprisingly little is known about how schools in different countries actually use their decision-making authority.

In this highly contentious field, there is a pressing need to advance our knowledge about the pros and cons of school autonomy and which specific forms of school autonomy result in better outcomes for students. A real hindrance herein is the lack of an adequate and widely used set of definitions. Current indicators to capture school autonomy are insufficient and give rise to flawed conclusions (You and Morris 2016). Despite an extensive review of the literature, no existing classification was found to be adequate for capturing the actual use of school autonomy. An internationally growing knowledge base requires a classification scheme to distinguish the relevant areas of school autonomy in sufficient detail, that can be used by researchers in a wide range of contexts. This article presents the empirical construction of such a classification.

Key questions underlying the classification are: What school interventions do schools consider and start in a context of increasing school autonomy and 
intensified accountability? Which areas of school autonomy do schools exercise in practice? To answer these questions a study was carried out in the Dutch education system. Together with a few other systems, schools in the Netherlands "enjoy the greatest autonomy" (OECD 2016b). There is no national curriculum, and schools are largely free to choose what to teach and how to teach it. Dutch schools have extensive freedom on matters regarding the organization of instruction, personnel management, and resource management (OECD 2012). This high level of school autonomy makes the Dutch education system an exemplary setting to study the potential range of school interventions.

In a deliberate attempt to grasp the full potential range of actual school interventions, a digital questionnaire with open-ended questions was composed. For the same reason, a school intervention was broadly defined as a planned action that is intended to cause change in the school. The questionnaire was distributed among school leaders, as the school leader is the person with the ultimate process responsibility for school operations (Pont et al. 2008) and, as such, the executive or final arbiter of decision-making at the school level (Spillane and Lee 2014, p. 435). Almost 200 school leaders replied to the questionnaire, providing information on more than 700 school interventions.

The classification presented in this study enables the identification, analysis, and comparison of school autonomy enacted in schools. It can be used on the local, national, or international level by policy-makers, training institutes, and researchers alike in their joint quest for "continuous improvement in the quality of education" (UNESCO Education Sector 2016). Accumulating knowledge regarding the actual use of school autonomy will further understandings of the potential levers of school improvement, school effectiveness, and educational change internationally.

The following sections provide a detailed description of the development and validation of the classification. To ensure an unambiguous interpretation of the study's approach and findings, in the first two sections, the key concepts are defined, and the relevant contextual elements described. Then, the theoretical background is presented, followed by an elaboration of the methodology. The actual classification is subsequently presented, including definitions and examples. In the concluding section, the strengths and weaknesses of the classification are discussed, and illustrations given as to its use.

\section{Concepts}

\section{School interventions}

In this study, a school intervention is broadly defined as a planned action intended to cause change in the school. This change can be both an adjustment to current school practices and the start of something new. In an attempt to grasp the potential range of actual school interventions, this paper deliberately employs an expansive definition of the term. First, this broad definition includes all possible school decision-making areas. It is not limited to specific school decision-making domains, such as educational interventions or resource allocation. Second, the definition is 
not confined to innovations. Even though the (perceived) difference between the two notions might seem minor, the term innovation connotes something new (Hellström 2004; Verschuren 2013) or "significantly improved" (Lubienski 2009, p. 19), rather than an adaptation of something already existing. An innovation can, be carried out by means of one or more interventions, whereas an intervention is not necessarily executed via one or more innovations. Decision-making responsibilities at the school level obviously entail more than simply innovation. This paper rests on the assumption that limiting the definition to innovations would have undervalued, or even ignored, large parts of actual decision-making at the school level. Third, this paper studies school interventions in their initiation phase. This stage is also known as the mobilization or adoption phase. It consists of one or more elements that precede and include a decision on whether to adopt or proceed with an intervention (Fullan 2001). Studying school interventions in the initiation phase means that interventions are relevant from the moment they are first considered, regardless of the outcome of that deliberation phase. Thus, this study included interventions that school leaders had considered-or were considering — but had deliberately not (yet) introduced. Limiting the focus on interventions that made it to the implementation phase might have systematically biased the view of the range of school autonomy.

\section{School autonomy}

The dictionary defines autonomy as "self-governing," which in turn means "functioning without the control of others" (Levacic 2002, p. 187). Whereas some studies have interpreted autonomy in a twofold manner as both the freedom and capacity to act (e.g. Gawlik 2008; Helgøy et al. 2007; Lidström 1991) or have focused on capacity (e.g. Agasisti et al. 2013), most analyses have used a definition deriving from the freedom to act. Anderson (2005, p. 73), for example, found "an autonomous organisation [...] responsible for making decisions about a pre-determined set of issues relating to its governance and mode of operation." According to Hooge (1995, p. 1), "the autonomy of a school refers to its degree of self-government in relation to the degree of state intervention." Similar interpretations of school autonomy were applied by Whitty (1997, p. 3), who defined school autonomy as "moves to devolve various aspects of decision making [...] to individual public schools." Honig and Rainey (2012, p. 467) described it as "increased discretion over particular decisions." Woessmann et al. (2009) emphasized the delegation of a task to a school by an agency with authority over that institution. In line with this paper's aim, school autonomy is defined as a school's right of self-government-encompassing the freedom to make independent decisions-on the responsibilities that have been decentralized to schools.

\section{School leaders}

School leaders play a central role in initiating changes in schools (Fullan 2001; Pont et al. 2008). Together, increasing school autonomy and intensified accountability standards have led to an increase in school leader decision-making responsibility in 
the last few decades (Glatter 2002; OECD 2016b). Despite current interest in distributed leadership (Bush and Glover 2014), each school is ultimately headed by a single individual who bears the ultimate process responsibility and who is accountable for the institution's operation (Earley and Bubb 2013; Spillane and Lee 2014; Wildy et al. 2004). In this study, this single individual is referred to as the school leader. ${ }^{1}$ Given that figure's position as the decision-making executive at the school level, this study was carried out among, and with, school leaders with the ultimate process responsibility for their school location(s).

\section{Context}

\section{School autonomy in the Dutch education system}

Compared to education systems in other member countries of the Organisation for Economic Co-operation and Development (OECD), schools in the Netherlands operate in a highly autonomous policy context (OECD 2012). ${ }^{2}$ Within a framework of learning objectives, standardized examinations, and block grants set by the national government, the administration of Dutch schools is highly decentralized. In lower secondary schools, $86 \%$ of "key decisions" on matters regarding the organization of instruction, personnel management and resource management are made at the school level, as compared to the OECD average of $41 \%$ (OECD 2012). Since there is no national curriculum, schools are largely free to decide what to teach and how to teach it, as long as they meet established quality standards and learning objectives. School autonomy is balanced by a set of standards, attainment targets, and a national examination system developed by the government (OECD 2016a). The Inspectorate of Education, under the responsibility of the Minister of Education, monitors both the quality of education and compliance with statutory and financial rules and regulations (Nusche et al. 2014). The Dutch Constitution guarantees school autonomy in accordance with the principle of 'freedom of education'. Since 1917, schools have been free to choose and follow their own pedagogical visions (Waslander 2010, p. 401). Due to the high level of school autonomy regarding a broad range of decisionmaking areas, the Dutch education system was considered an exemplary setting to study the potential spectrum of school interventions.

\footnotetext{
1 Whenever the term school leader is used in this article, it covers equivalent terms such as principal, head teacher, director, rector, or location/sector/departmental/general manager.

2 According to the OECD definition, the school level refers to "the individual school level only and includes school administrators and teachers or a school board or committee established exclusively for that individual school. The decision-making body-or bodies-for this school may be: an external school board, which includes residents of the larger community; an internal school board, which could include headmasters, teachers, other school staff, parents, and students; and both an external and an internal school board" (OECD 2012, p. 509).
} 


\section{Secondary education in the Netherlands}

With seven possible tracks, Dutch secondary education has the most differentiated systemic structure of all OECD countries (OECD 2015). Bounded by the primary school's advice, parents and students are free to choose a suitable school for secondary education. Most secondary schools offer more than one track and pupils can-to a certain extent - transfer between these tracks and between schools. Consequently, school choice provokes competition among individual schools (Gaskell 2002; Hirsch 1995; Woessmann et al. 2009). That competition, in turn, induces "incentives for institutions to organise programmes and teaching in ways that better meet diverse student requirements and interests" (OECD 2013, p. 133). Although this study could have been performed in any sector of the Dutch education system, secondary education was selected for its organizational complexity. Being the transitional link between primary and tertiary education, secondary education is characterized by ever-present multiple interests, concerns, and stakeholders. The sum of school choice, a highly tracked structure, and organizational complexity was expected to produce a diverse assemblage of school interventions.

\section{School leaders in Dutch secondary education}

In the Netherlands, secondary education school leaders are appointed by, and accountable to, school boards (OECD 2014a). School boards oversee the implementation of legislation and regulations in the school, and they employ teachers and other staff (Nusche et al. 2014). When a school board consists of only one school, the board and the school are part of the same legal entity, and a single person performs the functions of chair of the executive board and school leader (OECD 2016a). Despite school boards being formally responsible and accountable for the corporate and educational quality of the school (OECD 2016a), in practice, a vast share of decision-making power is delegated to the school management. Although the role and responsibilities of Dutch school leaders have not been formalized, "everybody looks to the school leader to guide decision-making in the school" (OECD 2016a, p. 143). Most school leaders "are responsible for financial matters and for ensuring that teaching and learning comply with the school's educational goals and standards" (OECD 2014a, p. 10). Decision-making powers for most matters related to human resources are delegated to school leaders as well (Eurydice 2007).

Dutch legislation contains no regulations about school leaders, "neither about duties, functions or authority nor about the qualifications or quality and competences" (Bal and De Jong 2007, p. 7). Consequently, no official distinction is made among the different hierarchical levels of school leaders. This means that the group of 3227 people holding a "school management" position in 2013 (Stamos 2015) included middle leaders: school leaders without the ultimate process responsibility for the school location(s). To estimate the number of school leaders falling within the school leader definition used in this study, a database from the Dutch executive organization responsible for the financing of educational institutions was used. 
This database contained all secondary school locations (both main locations and branch locations), counting 1414 such sites as of July 1, 2015 (DUO 2015). Following the definition that school leaders are those functionaries with the ultimate process responsibility for their school location(s), that number is likely to approximate the number of school leaders as defined in this study. Some school leaders are responsible for more than one school location, with no separate school leader at each of those sites. Other school leaders are responsible for more than one school location featuring a separate school leader. Both organizational models are likely roughly equal in number. Private schools were not included in the file. Since private schools essentially offer the same types of education as publicly funded schools and also have to fulfil equal accountability demands, the 29 private secondary-school locations as listed on a website for private education (Private Education in the Netherlands 2015) were included in the study. Together, this resulted in 1443 secondaryschool locations. ${ }^{3}$ This number approximates the number of school leaders with the ultimate process responsibility in Dutch secondary education.

\section{Theoretical background}

To define the key concepts underlying this study, an extensive literature review was conducted on the topics of school autonomy, school interventions, and school leadership. The definitions that derived from that search, presented above, were used in the questionnaire and to demarcate the response group. Subsequently, these concepts were studied in the context of Dutch secondary-education school leaders.

To explore the existence of classifications in various educational research traditions and their applicability for categorizing the school interventions from the questionnaire, an additional search in the Education Resources Information Center (ERIC) collection was carried out using the following combinations of key words: "school and autonomy," "principal and autonomy," "head and teacher and autonomy," "school and leader and practice," "principal and practice," "principal and policy and practice," "school and leader and policy and practice," "school and policy and intervention," "school and leader and intervention," and "decision and making and school and leader." This search yielded 579 unique documents. All studies with abstracts referring to school autonomy, school policy practices, school (leader) decision-making, school functions, leadership practices, leadership time use, school improvement, interventions, or innovations (excluding single improvements, interventions, or innovations) were taken as a starting point to further explore suitable classifications. The studies that provided such classifications are presented in Table 1, which organizes them by research discipline in alphabetical order.

To display the data (see "Methodology" section), the classifications from the studies presented in Table 1 were used for a first, rough categorization of the data. However, the classifications were, for various reasons, found insufficient to

\footnotetext{
${ }^{3}$ Secondary special education was not included in this research project, as that type of education falls under different legislation and accountability criteria.
} 
Table 1 Studies with potentially suitable classifications for the categorization of the school intervention dataset, organized by research discipline in alphabetical order

Educational (school) change

(Educational) innovations

Leadership practices: roles and behaviors

Leadership practices: time use

Organization development in schools

School autonomy and decision-making discretion

School effectiveness

School improvement
Earley, 2013; Frederiks \& De Bie, 2004; Fullan, 1998, 2001; Hargreaves \& Goodson, 2006; Kärkkäinen, 2012; Lagerweij \& Lagerweij-Voogt, 2004; Leune, 2001; Regtering \& Van den Broek, 2011; Slavin, 2005; Vieluf et al., 2012; Vodegel et al., 2015; Wonderen, 2004; Wrigley, 2011

Blank et al., 2009; Busman et al., 2006, 2007; Emmelot et al., 2008; Frederiks \& De Bie, 2004; Hofman et al., 2007; House, 1974; Kärkkäinen, 2012; Klein et al., 2008; Lagerweij, 1987; Lubienski, 2009; OECD, 2014b; OECD/Eurostat, 2005; Regtering \& Van den Broek, 2011; Scheerens, 2010; Verbiest, 2011; Vodegel et al., 2015; Waslander, 2007; Wonderen, 2004

Adamowski et al., 2007; Andersen \& Krüger, 2013; Barnett, 2000; Bird et al., 2013; Cheng, 2002; Day et al., 2016; Dempster, 2009; Earley, 2013; Hallinger, 2003; Hendriks \& Scheerens, 2013; Hendriks \& Steen, 2012; Krüger \& Scheerens, 2012; Leithwood, 2005; Leithwood et al., 2004, 2006; Leithwood \& Jantzi, 1999; Marzano et al., 2005; May et al., 2012; OECD, 2014c; Pont et al., 2008; Robinson et al., 2008, 2009; Scheerens \& Steen, 2012; Schmidt, 2009; Townsend \& MacBeath, 2011

Bristow et al., 2007; Earley, 2012; Earley \& Bubb, 2013; Grissom et al., 2015; Lee \& Hallinger, 2012; OECD, 2014c

French \& Bell, 1999; Fullan et al., 1980; Schmuck \& Miles, 1971; Schmuck \& Runkel, 1985

Anderson, 2005; Bolam, 1993; Galway \& Sheppard, 2015; Glatter, 2002; Hanushek et al., 2013; Leune, 2001; Levacic, 2002; Maslowski et al., 2007; OECD, 2011, 2012, undated; Paletta, 2014; Smith, 2011; Steinberg, 2012; Triant, 2001; Wildy et al., 2004; Wohlstetter et al., 1995

Creemers \& Kyriakides, 2010; Creemers \& Reezigt, 1997; Hattie, 2009; Hendriks \& Scheerens, 2013; Kyriakides et al., 2010, 2015; Kyriakides \& Tsangaridou, 2008; Marzano, 2003; Reynolds, 2000; Reynolds et al., 2014; Scheerens, 2016

Barth, 1990; Creemers \& Reezigt, 1997; Hopkins, 2001; Hopkins et al., 2014; Hopkins \& Levin, 2000; Hopkins \& Reynolds, 2001; Mourshed et al., 2010; Reynolds et al., 2000; Seashore Louis, 2005; Seashore Louis et al., 1999; Wrigley, 2008

distinguish the school interventions conveyed by the school leader respondents. The classifications' generic features and limitations in the context of this study are presented in Table 2, which again organizes them according to research discipline. 
Table 2 Generic features and limitations of the classifications from the studies presented in Table 1, organized by research discipline in alphabetical order

Educational (school) change

(Educational) innovations

Leadership practices: roles and behaviors

Leadership practices: time use

Organization development in schools

School autonomy and decision-making discretion
The classifications in these studies focused on change in the educational domain (i.e., change related to educational processes). In this study, school intervention practice also included school change related to organization and staff domains. The scope of these classifications hence proved too narrow for categorizing the complete school intervention dataset

The classifications in these studies focused on school interventions aimed at innovation. As defined in this paper, school interventions do not necessarily or solely aim at innovation. The scope of these classifications therefore proved too narrow for categorizing the full school intervention dataset

School leaders' roles and behaviors have certain commonalities with school interventions executed by school leaders. However, roles and behaviors are different ordering categories than interventions. Consequently, various classifications in this field contained categories that were not recognized in the school intervention dataset. Examples of such categories are role modelling, flexibility, and beliefs. Additionally, other classifications in this field covered most or all of the school interventions but used few categories - with very broad definitions - and hence lacked sufficient depth and detail to allow for meaningful distinctions

Leadership practices with regard to time use have commonalities with school interventions, as both center around actions or activities. Leadership time-use practices, however, tend to focus on those activities performed by school leaders themselves. The school interventions that are gathered from the school leader survey in this study may be intended for, or performed by, others in the school. For this reason, leadership time-use classifications proved too narrow in scope for categorizing the complete school intervention dataset

The classifications in these studies primarily emphasized organization development implementation designs and processes in schools, rather than the specific content of actual improvement efforts. For this reason, they were too generic for categorizing the school interventions from the dataset

The classifications in these studies were either too confined in scope (e.g. reflecting the narrower range of school autonomy in a particular education system) or displayed few categories - with very broad definitions-resulting in a lack of the depth and detail needed for meaningful distinctions 
Table 2 (continued)

School effectiveness

School improvement
Since school interventions include a wider range of activities than those that have (thus far) been subject to (meta) effectiveness research, the categorizations in these studies proved too limited in scope for this specific dataset

The classifications in these studies were either too confined in scope (e.g. reflecting the narrower range of school autonomy in a particular education system) or displayed few categories-with very broad definitions-resulting in a lack of the depth and detail needed for meaningful distinctions

As Table 2 testifies, current classifications stem from multiple research traditions, each emphasizing a particular area of responsibility. Each scheme serves its primary purpose within its own field of study. Shifting the perspective to a broad definition of school interventions and to school leaders, who bear the responsibility for a wide range of interventions, existing classifications fell short. They were either too detailed in one area or too broad in another. In other cases, schemes excluded whole areas of responsibilities altogether. Combining existing classifications proved highly challenging, because each tended to follow its own structure, abstraction level, and logic. Therefore, a completely new empirically based classification was constructed. One that provided sufficient breath to capture the whole range of school interventions, along with enough depth and detail to allow for meaningful distinctions. That scheme also featured a clear logic and structure to enhance usability. The classification was constructed from the school interventions captured during the field-work phase of this study and in continuous dialogue with school leaders. It thus coincided with decision-making responsibilities at the school level as perceived by Dutch secondary-education school leaders. The following section elaborates on the approach used to construct and validate the classification.

\section{Methodology}

First, the general principles underlying this study's mixed-methods approach are clarified. Subsequently, the various elements of that approach-drafting the questionnaire; collecting the data; reducing and displaying that data; drawing and verifying conclusions-are described in more detail.

\section{Mixed-methods approach}

This study relied on a mixed-methods approach. Johnson et al. (2007, p. 123) have defined mixed-methods research as a type of research in which "elements of qualitative and quantitative research approaches [are combined] for the broad purposes of breadth and depth of understanding and corroboration." The combination of qualitative and quantitative methods is regarded as one form of triangulation, namely, 
methodological triangulation (Tashakkori and Teddlie 1998). Following Flick's (2009, p. 444) interpretation, this study pursued methodological triangulation as a strategy for "further enriching and completing knowledge and towards transgressing the (always limited) epistemological potentials of the individual method."

This study's mixed-methods approach followed the three "concurrent flows of activity" of analysis - data reduction, data display, and drawing and verification of conclusions - as discerned by Miles and Huberman (1994, pp. 10-11). This procedure was adopted due to the iterative character of the combined activities. In this sequence, which started with exploratory field-work in search of "conceptualization and shared meaning" (Babbie 2004, p. 146), a quantitative instrument (i.e., a questionnaire) with a qualitative design (i.e., open-response questions) was used to gather data on the unit of analysis: school interventions. As the goal was to consider the full potential scope of school interventions, it was deemed essential to avoid predefining or limiting the input beforehand, as the spectrum of such interventions was expected to be diverse, and perhaps even unexpected. For this reason, the questionnaire was based on open-response questions.

Following Miles and Huberman's (1994, p. 6) interpretation of Verstehen, this paper rests on the assumption that a classification used to identify and analyze the actual use of school autonomy should ideally be based on ongoing consultations with school leaders-as the interpreters of school autonomy - throughout the entire construction phase. Hence, in a deliberate attempt to increase the study's face and content validity (Babbie 2004; Bartlett and Burton 2012), school leaders were actively involved in all stages of the study (i.e., not only in elaborating the study's aim, context, and key concepts, but also in drafting the questionnaire, testing the instrument, interpreting the outcomes, and constructing and refining the classification). By means of this continuous dialogue, school leaders' practical experiences served both as the start and finish of the construction process. The various elements of the mixed-methods approach are explained in more detail in the following sections.

\section{Drafting the questionnaire}

A digital questionnaire was used for the large-scale collection of data on school interventions among school leaders. Unlike qualitative research instruments, such as interviews and observations, a questionnaire can potentially gather input from a relatively large number, variety, and random assortment of respondents in a comparatively short time span (Bartlett and Burton 2012). The first draft of the questionnaire was tested by means of semi-structured interviews with two chairpersons of executive boards and one middle manager from secondary education, as well as with one chairperson of an executive board and three school leaders from primary education. To prevent any biases, which could have limited the pool of potential secondary-education school leader respondents, a deliberate choice was made to test and discuss various questionnaire drafts with both other individuals in secondary-education managerial positions and primary-education school leaders. Since this study could have been carried out in primary education with equal effectiveness, testing and discussing draft questionnaires 
with primary-education school leaders appeared to be a sound way to avoid excluding likely respondents.

The main aim of this series of interviews was to test the comprehensibility of the questionnaire's design and contents by means of member checks (Bartlett and Burton 2012; Flick 2009). During these interviews, the researcher orally posed the draft questions, and the participants verbally responded. All interviews provided ample time for the interviewees to make additional remarks and for the researcher to ask follow-up questions. Based on the interviewees' answers, remarks, and questions, the researcher shortened the questionnaire, rephrased various questions and definitions, and added an introductory text explaining the survey's aims and key concepts. For illustration, one rephrasing that resulted from these interviews concerned the definition of a school intervention. In the first draft of the questionnaire, an intervention was defined as a planned action intended to induce an improvement in a school. However, one of the chairpersons noted that the term improvement might cause "allergic reactions" among certain school leaders due to the connotation of accountability for educational outcomes. The interviewee expected that this association would hinder constructive responses to the questions and suggested the use of a more neutral term, such as change. Moreover, that participant pointed out that change is a more comprehensive term than improvement. In this respect, Cuban (1988, p. 341) mentioned that "change is not necessarily improvement." Apart from a more neutral connotation, this broader definition of the unit of analysis was closely aligned with the study's aim of capturing the range of actual school interventions. The altered definition was thereafter tested in the other interviews. The observation was confirmed, and in consequence, the alteration was definitively applied.

An adjusted version of the questionnaire was tested in a series of four individual, semi-structured interviews with primary-education school leaders. Each interview started with the interviewee completing the questionnaire in writing-without any oral explanations from the researcher. Subsequently, the researcher and the interviewee engaged in an exchange about the overall intelligibility of the questionnaire, its individual questions, the explanation of key concepts, and the introductory text. Each of the interviews was furthermore used to measure completion times and to test suggestions made by previous interviewees. Written and verbal input from the respondents again led to reconsiderations and subsequent adaptations regarding the phrasing of the questions, the key concepts, the introductory text, and the scope of the survey as a whole. An example of an adaptation was the restoration of several questions that had previously been deleted to keep the questionnaire manageable for the respondents in terms of the completion time. Various questions were restored when the first two interviewees both completed the questionnaire within $5 \mathrm{~min}$. All suggested adaptations were tested in the successive interviews. The questionnaire thus evolved via an intense dialogue with, and the involvement of, school-level decision-makers.

\section{Questionnaire distribution and response}

In total, 543 school leaders received a direct email invitation from the researcher to fill out the digital questionnaire. The names and email addresses were partly 
Table 3 Distribution of the questionnaire invitations directly sent by the researcher

\begin{tabular}{lcc}
\hline Invitations sent to & Number & Total \\
\hline School leaders from network & 57 & \\
School leaders from random internet search & 486 & 543 \\
School leaders total & & \\
Executive board members from network & 20 & \\
Executive board members from random internet search & 43 & 64 \\
Executive board members total & 37 & 37 \\
Other functionaries from network & & 644 \\
Other functionaries total & & \\
Total invitations sent & & \\
\hline a & &
\end{tabular}

${ }^{\text {a }}$ The 24 invitations that were not delivered due to an incorrect email address are not included in this table

gathered from the network of the researcher and partly from a random internet search. In addition to being requested to complete the questionnaire, the school leaders were kindly asked to forward the invitation to other school leaders in their networks. The invitation clearly stated what type of school leader-those with the ultimate process responsibility for their school location(s)—was invited to participate in the questionnaire. Names and email addresses of executive board members and other functionaries (middle leaders and staff officials) were also collected - again, both from within the researcher's network and from a random internet search-and those individuals were asked to forward the invitation to school leaders in their organizations and networks. The distribution of invitations sent by the researcher is presented in Table 3.

After a round of reminder emails, 196 school leaders completed the questionnaire. Based on the previously mentioned figure of 1443 secondary school leaders, approximately $14 \%$ of all Dutch secondary school leaders with ultimate process responsibility finished the questionnaire. Since each person that received an invitation was asked to forward the invitation to other school leaders in his or her network, determining the response rate was not possible.

Even though the population that received an email invitation was, by design, not completely random, the distribution of various Dutch secondary school characteristics across both the response group and the total number of school locations (DUO 2015) did not demonstrate any substantial anomalies. With regard to the distribution of respondents over the 12 Dutch provinces, all territories were reasonably represented. The relatively high percentage of Limburg-based schools is attributable to the fact that the researcher's affiliation is situated in that region, resulting in a larger network in that specific province. All education types (e.g. public, private, religious) were represented among the respondents' schools, and the corresponding distribution did not exhibit any pronounced anomalies. The distribution of schools across Dutch educational tracks (e.g. vocational, general, combined) indicated a slightly larger divergence between the sample and the allschools database than for the two previously mentioned school characteristics. 
Again, however, all the different tracks and combinations of tracks possible within the Dutch education system were present among the respondents.

\section{Data reduction, data display, and the drawing and verification of conclusions}

The questionnaire asked the school leaders to list up to three school interventions that had been introduced in the past school year (2013-2014) or that were intended to start in the current school year (2014-2015). The respondents were also asked to list up to three school interventions that had been considered in the past or current school year but were deliberately not introduced. This latter question was included to maximize the scope of potential school interventions and minimize any systematic bias concerning the use of school autonomy. The questionnaire collected a maximum of three interventions per question to ensure that it would be manageable for, and inviting to, the respondents. These two open-response questions collected 595 (to be) introduced interventions and 140 interventions that had been considered but not introduced. Data reduction (Miles and Huberman 1994) commenced for these 735 items.

After extensive literature review and subsequent exploration of suitable existing classifications from the studies listed in Tables 1 and 2, the next step was to display the data on the actual school interventions captured from the questionnaire. Each intervention was grouped with thematically comparable interventions to form subdomains of school interventions. Each of these subdomains was given a working title and a working definition based on the characteristics of the assembled interventions. For the classification's structural logic, three overlying domains were added.

The verification (Miles and Huberman 1994) of various draft classifications was pursued via a series of semi-structured interviews with four secondary-education school leaders at different stages of the drafting process. The open-response design of the questionnaire had led to a rich but complex dataset. In an attempt to solicit diverse reflections on the drafts that originated from that dataset, school leaders representing diverse school and school-leader characteristics were invited. Three of the four school leaders had participated in the questionnaire. These interviews were used, first, to verify the interpretation of the freely formulated school interventions to enhance the classification's face validity. Second, the interviews served to test the content validity of the classification-regarding the (sub)domains, definitions, and distribution of the school interventions-in the eyes of those exercising school autonomy.

Each interview started with a brief outline of the study's aim, followed by a presentation of the latest draft of the classification. Subsequently, the researcher provided an overview of the different domains and subdomains, the accompanying definitions, and the distribution of the school interventions per subdomain. In each interview, the school leaders were asked whether the distinctions among the various domains, subdomains, and definitions made sense from the perspective of their own school practice. The interviewees were also asked whether and how the classification could be further improved. Any suggestion made by an individual school leader regarding the classification's (sub)domains, definitions, 
or grouping of interventions was discussed with the school leaders in subsequent interviews. As such, none of the adaptations was based on singular insights or views. In the interviews, special attention was given to those (sub)domains, definitions, and intervention groupings that were questionable in the eyes of the researcher.

These interviews with the school leaders led, as expected, to adjustments to various aspects of the classification. For example, at the start of the drafting process, four main school intervention domains were distinguished: the current domain of "education" was split into "educational concepts" and "educational programs." However, the interviewed school leaders unanimously expressed a strong preference for differentiating among three main school intervention domains, namely, "education" "organization" and "staff" (see Table 4). All other decision-making areas, in their opinion, stem from one of those three fields. Interestingly, these three domains coincide with the three areas of school autonomy that the OECD (undated) defined in its Improving School Leadership project. A second example of a practical adjustment concerned the "organization" domain. This domain was initially called "operational management." Multiple school leaders, however, indicated that this latter term evokes (highly) negative connotations among many educational practitioners for its perceived relation to business settings. For this reason, the school leaders strongly recommended using the term "organization" instead. A third example concerned one school leader's suggestion to replace the term "staff" in the corresponding domain with the-in his opinion-more appropriate term "employees." This suggestion was refuted by all of the other school leaders and the term "staff" was maintained. Other adjustments stemming from the interviews concerned the extension or disentanglement of subdomains and the regrouping of school interventions.

\section{The classification}

Thus, starting from a set of definitions derived from a thorough literature review, rich data gathered from a considerable number of diverse school leaders by means of open questions, an extensive exploration of the applicability of existing classifications, and an ongoing dialogue with school-level decision-makers, an empirically based classification of school interventions was constructed. The school leaders' suggestions and the adaptations made throughout the verification process resulted in a classification of school interventions that adequately reflected the range and content of the decision-making responsibilities and autonomy perceived by Dutch secondary school leaders in their daily practice. This classification, which is presented in Table 4, is organized via the three main domains of "education," "organization," and "staff." Each of these domains consists of various subdomains, with the entire framework composed of 16 such subdomains. Each subdomain is accompanied by a definition and a cross-section of corresponding school interventions from the dataset. 
Table 4 Classification scheme of school interventions

Subdomain Definition

\section{Education}

Pedagogical approaches

Educational programs

Systemic pathways

Learning environments and methods for teaching, learning, and assessment

\section{Organization}

School culture
Interventions concerning the design or elaboration of (effective) teaching, learning, or educational processes in the direct interaction between teacher(s) and student(s). Interventions concerning what is often labelled as "classroom management" are included in this domain

Examples ${ }^{\mathrm{a}}$ : interdisciplinary teaching; project-based education; demand-driven education; homework-free school; area-based learning; new didactic approaches; activating pedagogy; custom-made pedagogical approaches; personalized learning; dealing with differences; teaching children at their own level

Interventions concerning lessons, subjects, courses, or programs offered in a school ${ }^{\mathrm{b}}$ (track) and formalized within the curriculum of a school (track). Interventions concerning formalized extracurricular activities are included in this domain

Examples: bilingual education; additional subjects; culture profile school; technical profile school; personal development program; new literacy and numeracy program; anti-bullying program; more sports; talent program; extra attention to skills in the curriculum

Interventions concerning the systemic pathways through the education system that transcend the boundaries of regular school tracks and moments of assessment or examination

Examples: accelerated pathways to a diploma; possibility to obtain a secondary vocational education diploma at a pre-vocational secondary education school; start of a mixed pre-vocational secondary education program; craftsmanship route; technology route; availability of secondary vocational education at own school by own teachers

Interventions concerning the learning environment and the methods and tools used for teaching, learning, and assessment, including digitalization

Examples: new approach to assessment; new teaching method; evaluation of the assessment program; adapted learning environment; iPad class; bring your own device (BYOD); classroom laptops; laptop/tablet-oriented education; electronic learning environment; information technology applications

Interventions concerning the school's mission, vision, identity, culture, or image (positioning), including strategic policy-making

Examples: recalibrating the school plan, mission, or vision; change in school culture; policy development; positive behavior support (PBS); The Peaceful School (a school identity program); re-profiling; non-smoking school 
Table 4 (continued)

\begin{tabular}{|c|c|}
\hline Subdomain & Definition \\
\hline Organizational structures & $\begin{array}{l}\text { Interventions concerning the school's organizational } \\
\text { structure(s) } \\
\text { Examples: changing the team or management structure; } \\
\text { improving the functioning of the teams; clustering/merg- } \\
\text { ing of locations; changing the organizational model; } \\
\text { reallocating staff across teams; more autonomy on the } \\
\text { team level }\end{array}$ \\
\hline Organization of education & $\begin{array}{l}\text { Interventions concerning the set of rules, procedures, or } \\
\text { regulations related to the organizational design of educa- } \\
\text { tion } \\
\text { Examples: adapting procedures with regard to the repeti- } \\
\text { tion of classes, exam resits, student determination, or } \\
\text { absence; change in class hours; class groupings }\end{array}$ \\
\hline Quality assurance & $\begin{array}{l}\text { Interventions concerning all standardized activities to meet } \\
\text { quality requirements and goals for services, activities, } \\
\text { and products. This domain includes the use of research } \\
\text { as an evaluation method, as well as outcome- or result- } \\
\text { based working approaches } \\
\text { Examples: introducing an outcome-based or result-based } \\
\text { working approach; improvement programs for bet- } \\
\text { ter educational outcomes; standardized assessments; } \\
\text { improvement plans by teams; research on the educational } \\
\text { pathways of migrant girls; school evaluation; monitoring } \\
\text { social-emotional development; introduction of a data } \\
\text { team }\end{array}$ \\
\hline Student care and support & $\begin{array}{l}\text { Interventions concerning student-oriented care, guidance, } \\
\text { or support } \\
\text { Examples: developing additional care and support for } \\
\text { pupils with special needs; introducing student coaching; } \\
\text { more elements of the support structure in classrooms }\end{array}$ \\
\hline Stakeholder relationships & $\begin{array}{l}\text { Interventions concerning the relationships with, or involve- } \\
\text { ment of, the school's stakeholders, such as parents, } \\
\text { primary and tertiary education, other secondary schools, } \\
\text { the (local) community, or (local) industry } \\
\text { Examples: increased cooperation with primary or tertiary } \\
\text { education, parents, industry, community, or secondary } \\
\text { schools (outside own educational institution); sharing } \\
\text { science lab with primary education; participating in a } \\
\text { network; staying in contact with community or society }\end{array}$ \\
\hline Financial resources & $\begin{array}{l}\text { Interventions concerning the school's financial resources } \\
\text { Examples: aiming for 'healthy' finances; drafting of a new } \\
\text { financial framework; improving financial situation }\end{array}$ \\
\hline Facilities and accommodation & $\begin{array}{l}\text { Interventions concerning the school's facilities or } \\
\text { accommodation(s) } \\
\text { Examples: improvement to the building; school stewards; } \\
\text { Wi-Fi throughout the entire building; providing laptops } \\
\text { to all teachers }\end{array}$ \\
\hline
\end{tabular}


Table 4 (continued)

\begin{tabular}{ll}
\hline Subdomain & Definition \\
\hline Staff & \\
Professional autonomy and culture & Interventions concerning the staff's professional autonomy \\
& or professional culture (behavior). This domain includes \\
& training and development activities and peer col- \\
& laboration to increase the level of staff professionalism \\
& (capacity-building) \\
Examples: staff development project; training program \\
with regard to new media; more professional autonomy \\
for teachers; working towards a learning organiza- \\
tion; stimulate an inquisitive mentality among teachers; \\
strengthening school leadership; mutual teacher feed- \\
back; classroom visits by team leaders; peer reflection; \\
cooperation within professional learning communities; \\
on-the-job learning from peers; video interaction pro- \\
grams; peer intervision
\end{tabular}

Teaching- and school- related assignments Interventions concerning the distribution of teaching and other school-related duties and assignments

Examples: recalibrating policies with regard to the distribution of teaching and other school-related duties and assignments; job-matching

Staffing policy: assessment and payment Interventions concerning staffing policy, assessment, or payment

Examples: recalibrating staffing policies; (re)introducing the (performance management) review cycle; renewal of reward (payment) policies; introducing assessments

Recruitment and employment

Interventions concerning recruitment or employment

Examples: employing new staff members; recruiting staff with a university background; dismissing low-performing staff members

\footnotetext{
${ }^{a}$ All examples presented in Table 4 are derived from the questionnaire responses (translated from Dutch into English)

${ }^{\mathrm{b}}$ In all definitions, the term school also covers a group of schools or institution
}

\section{Conclusion}

In many countries, education systems are moving towards increased school autonomy and intensified accountability (Cheng et al. 2016; Helgøy et al. 2007). Consequently, decision-making at the school level has become paramount (Imants et al. 2016), and the role of the school leader has grown in importance (OECD 2016a). Surprisingly little is known about how schools and school leaders actually use school autonomy. To advance our knowledge in this field, an adequate classification is needed to capture the full range of school interventions in practice. An extensive review of the literature from various educational research disciplines revealed that none of the existing taxonomies met the requirements.

This article presented the construction and validation of an empirically based classification of school interventions that allows for the identification, analysis, and 
comparison of the actual use of school autonomy. The classification is based on responses of almost 200 secondary-education school leaders who conveyed a total of over 700 interventions. The study was set in the Netherlands which is known for its high level of school autonomy (OECD 2014a). To achieve practical (i.e., face and content) validation of the classification, school-level decision-makers were actively involved in all stages of the project. The classification has sufficient breath to capture the whole range of school interventions, enough depth and detail to allow for meaningful distinctions, and a clear logic and structure to enhance wide usability.

Despite deliberate efforts to construct a comprehensive classification suitable for international use, there are certain limitations. First, the classification was constructed in one particular setting. Although Dutch schools enjoy a very high level of school autonomy and have done so for a long time, that does not necessarily imply comprehensiveness. Schools in other education systems-even in those with a lower level of autonomy - may have decision-making authority in areas that have not come to light in the Dutch context. Second, even though professionals from primary education were involved in the study's design and refinement of the questionnaire, the dataset only included interventions in secondary schools. Small adaptations may be required for adequate use in primary education. Third, the classification is based on contemporary school interventions. For future use, the scope of the current domains or subdomains may need adjustments.

\section{Discussion}

Despite its limitations, the classification enables important steps forwards to advance our knowledge on school autonomy. A few examples can illustrate its potential use. The (sub)categories can be a starting point for first cycle coding of interviews with school leaders (Miles and Huberman 1994). It may, for example, further our understanding of how novice and experienced school leaders enact their decision-making authority in diverse international jurisdictions (Spillane and Lee 2014). The classification can also be used for in-depth comparisons between schools operating under different autonomy regimes, such as public and charter schools in the USA (Gawlik 2008). For large-scale data-collection, the construction of questionnaires and indicators can be based on this classification. It will make sense to school leaders, capture sufficient detail while at the same time allowing for aggregation and comparisons within and across countries. This will result in a more sophisticated description of school autonomy in different jurisdictions, which is needed to deepen our understanding about which particular combinations of high and low levels of school autonomy are likely to improve educational outcomes (Woessmann et al. 2009) while diminishing inequity (Werfhorst and Mijs 2010).

In all, this comprehensive classification may act as a stepping stone to make real progress in the much-debated field of school autonomy.

Acknowledgements The author wishes to thank all of the school leaders and chairpersons of executive boards who participated in this study for their input and reflection. She would also like to thank the anonymous reviewers for their valuable comments. 
Open Access This article is distributed under the terms of the Creative Commons Attribution 4.0 International License (http://creativecommons.org/licenses/by/4.0/), which permits unrestricted use, distribution, and reproduction in any medium, provided you give appropriate credit to the original author(s) and the source, provide a link to the Creative Commons license, and indicate if changes were made.

\section{References}

Adamowski, S., Bowles Therriault, S., \& Cavanna, A. P. (2007). The autonomy gap. Barriers to effective school leadership. Washington D.C.: Thomas B. Fordham Institute.

Agasisti, T., Catalano, G., \& Sibiano, P. (2013). Can schools be autonomous in a centralised educational system? On formal and actual school autonomy in the Italian context. International Journal of Educational Management, 27(3), 292-310.

Andersen, I., \& Krüger, M. (2013). Beroepsprofiel schoolleiders voortgezet onderwijs [Professional profile secondary education school leaders]. Utrecht, The Netherlands: VO-raad.

Anderson, L. (2005). Decentralization, autonomy and school improvement. In M. Coleman \& P. Earley (Eds.), Leadership and management in education. Cultures, change and context. Oxford: Oxford University Press.

Babbie, E. R. (2004). The practice of social research (10th ed.). Belmont, CA: Wadsworth.

Bal, J., \& De Jong, J. (2007). Improving school leadership: OECD review. Background report for the Netherlands. Zoetermeer: Panteia.

Ball, S. J., Maguire, M., \& Braun, A. (2012). How schools do policy: Policy enactments in secondary schools. Abingdon-on-Thames: Routledge.

Barnett, B. (2000). The changing external policy context and the role of the school principal. Nottingham, England: National College for School Leadership.

Barth, R. S. (1990). Improving schools from within: Teachers, parents, and principals can make the difference. San Francisco, CA: Jossey-Bass.

Bartlett, S., \& Burton, D. (2012). Introduction to education studies (3rd ed.). Los Angeles, London: SAGE.

Bird, J. J., Dunaway, D. M., Hancock, D. R., \& Wang, C. (2013). The superintendent's leadership role in school improvement: Relationships between authenticity and best practices. Leadership and Policy in Schools, 12(1), 77-99. https://doi.org/10.1080/15700763.2013.766348.

Blank, J., Haelermans, C., \& Van Hulst, B. (2009). Innovatiekracht van het voortgezet onderwijs [Innovation power in secondary education]. Utrecht, The Netherlands: Council for Secondary Education.

Bolam, R. (1993). School-based management, school improvement and school effectiveness. In C. Dimmock (Ed.), School-based management and school effectiveness. London: Routledge.

Bristow, M., Ireson, G., \& Coleman, A. (2007). A life in the day of a headteacher. A study of practice and well-being. Nottingham, England: National College for School Leadership.

Bush, T., \& Glover, D. (2014). School leadership models: What do we know? School Leadership and Management, 34(5), 553-571. https://doi.org/10.1080/13632434.2014.928680.

Busman, L., Horsmans, E., Klein, T., \& Oomen, C. (2007). Beweging in beeld. Feiten en verhalen over innovatie in het voortgezet onderwijs 2007 [Captured motion. Facts and stories about innovation in secondary education 2007.]. Utrecht, The Netherlands: VO-project Innovatie.

Busman, L., Klein, T., \& Oomen, C. (2006). Beweging in beeld. Feiten en cijfers over innovatie in het voortgezet onderwijs 2006. [Captured motion. Facts and figures about innovation in secondary education 2006]. Utrecht, The Netherlands: Schoolmanagers_VO.

Cheng, Y. C. (2002). The changing context of school leadership: Implications for paradigm shift. In K. Leithwood \& P. Hallinger (Eds.), Second international handbook of educational leadership and administration. Dordrecht, The Netherlands: Kluwer Academic Publishers.

Cheng, Y. C., Ko, J., \& Lee, T. T. H. (2016). School autonomy, leadership and learning: A reconceptualisation. International Journal of Educational Management, 30(2), 177-196. https://doi. org/10.1108/IJEM-08-2015-0108.

Creemers, B., \& Kyriakides, L. (2010). School factors explaining achievement on cognitive and affective outcomes: Establishing a dynamic model of educational effectiveness. Scandinavian Journal of Educational Research, 54(3), 263-294. 
Creemers, B., \& Reezigt, G. (1997). School effectiveness and school improvement: Sustaining links. School Effectiveness and School Improvement, 8(4), 396-429. https://doi.org/10.1080/0924345970 080402 .

Cuban, L. (1988). A fundamental puzzle of school reform. The Phi Delta Kappan, 69(5), 341-344.

Day, C., Gu, Q., \& Sammons, P. (2016). The impact of leadership on student outcomes: How successful school leaders use transformational and instructional strategies to make a difference. Educational Administration Quarterly, 52(2), 221-258.

Dempster, N. C. (2009). Leadership for learning: A framework synthesising recent research. Edventures, 1(13), 1-9.

DUO. (2015). School Locations in Dutch Secondary Education (1 July 2015 ed.).

Earley, P. (2012). Observation methods: Learning about leadership practice through shadowing. Journal of Educational, Cultural and Psychological Studies, 6, 15-31.

Earley, P. (2013). Exploring the school leadership landscape. Changing demands, changing realities. London, UK \& New York, NY: Bloomsbury Academic.

Earley, P., \& Bubb, S. (2013). A day in the life of new headteachers: Learning from observation. Educational Management Administration \& Leadership, 41(6), 782-799. https://doi.org/10.1177/17411 43213494189.

Emmelot, Y., Ledoux, G., Van der Veen, I., \& Breetvelt, I. (2008). Innovatiemonitor Primair Onderwijs [Innovation monitor Primary Education]. Amsterdam, The Netherlands: SCO-Kohnstamm Instituut.

Eurydice. (2007). School autonomy in Europe. Policies and measures. Brussels: Eurydice.

Flick, U. (2009). An introduction to qualitative research (4th ed.). Los Angeles, London: SAGE Publications.

Frederiks, P., \& De Bie, D. (2004). Waren we maar eerder begonnen. Over de aanpak van onderwijsvernieuwing. [If only we had started earlier. On the approach to educational innovation]. Houten, The Netherlands: Bohn Staflue Van Loghum.

French, W., \& Bell, C. (Eds.). (1999). Organisation development. Behavioral science interventions for organisation improvement (6th ed.). New York, NY: Prentice Hall Int.

Fuchs, T., \& Woessmann, L. (2007). What accounts for international differences in student performance? A re-examination using PISA data. Empirical Economics, 32, 433-464. https://doi.org/10.1007/ s00181-006-0087-0.

Fullan, M. (1998). The meaning of educational change: A quarter of a century of learning. In A. Hargreaves, A. Lieberman, M. Fullan \& D. Hopkins (Eds.), International handbook of educational change: Part one. Dordrecht, The Netherlands: Kluwer Academic Publishers.

Fullan, M. (2001). The new meaning of educational change (3rd ed.). New York, NY: Teachers College Press.

Fullan, M., Miles, M. B., \& Taylor, G. (1980). Organization development in schools: The state of the art. Review of Educational Research, 50(1), 121-183.

Galway, G., \& Sheppard, B. (2015). Research and evidence in education decision-making: A comparison of results from two pan-Canadian studies. Education Policy Analysis Archives, 23(109), 1-41.

Gaskell, J. (2002). School choice and educational leadership: Rethinking the future of public schooling. In K. Leithwood \& P. Hallinger (Eds.), Second international handbook of educational leadership and administration (Vol. 2). Dordrecht: Kluwer Academic Publishers.

Gawlik, M. A. (2008). Breaking loose. Principal autonomy in charter and public schools. Educational Policy, 22(6), 783-804.

Glatter, R. (2002). Governance, autonomy and accountability in education. In T. Bush \& L. Bell (Eds.), The principles and practice of educational management. London, England: Paul Chapman Publishing.

Grissom, J. A., Loeb, S., \& Mitani, H. (2015). Principal time management skills: Explaining patterns in principals' time use, job stress, and perceived effectiveness. Journal of Educational Administration, 53(3), 773-793. https://doi.org/10.1108/JEA-09-2014-0117.

Hallinger, P. (2003). Leading educational change: Reflections on the practice of instructional and transformational leadership. Cambridge Journal of Education, 33(3), 329-352. https://doi. org/10.1080/0305764032000122005.

Hanushek, E. A., Link, S., \& Woessmann, L. (2013). Does school autonomy make sense everywhere? Panel estimates from PISA. Journal of Development Economics, 104, 212-232. 
Hargreaves, A., \& Goodson, I. (2006). Educational change over time? The sustainability and nonsustainability of three decades of secondary school change and continuity. Educational Administration Quarterly, 42(1), 3-41. https://doi.org/10.1177/0013161X05277975.

Hattie, J. (2009). Visible learning: A synthesis of over 800 meta-analyses relating to achievement. New York, NY: Routledge.

Helgøy, I., Homme, A., \& Gewirtz, S. (2007). Local autonomy or state control? Exploring the effects of new forms of regulation in education. European Educational Research Journal, 6(3), 198-202.

Hellström, T. (2004). Innovation as social action. Organization, 11(5), 631-649. https://doi. org/10.1177/1350508404046454.

Hendriks, M., \& Scheerens, J. (2013). School leadership effects revisited: A review of empirical studies guided by indirect-effect models. School Leadership \& Management, 33(4), 373-394. https://doi. org/10.1080/13632434.2013.813458.

Hendriks, M., \& Steen, R. (2012). Results from school leadership effectiveness studies (2005-2010). In J. Scheerens (Ed.), School leadership effects revisited. Review and meta-analysis of empirical studies. Springer.

Hirsch, D. (1995). School choice and the search for an educational market. International Review of Education, 41(3-4), 239-257.

Hofman, W. H. A., Hofman, R. H., Dijkstra, B. J., De Boom, J., \& Meeuwisse, M. (2007). Innovaties in het voortgezet onderwijs. Een verkenning van innovaties en effecten in het voortgezet onderwijs. [Innovations in secondary education. An exploration of innovations and effects in secondary education.]. Groningen \& Rotterdam, The Netherlands: UOCG/GION \& RISBO Contract research BV.

Honig, M. I., \& Rainey, L. R. (2012). Autonomy and school improvement: What do we know and where do we go from here? Educational Policy, 26(3), 465-495. https://doi.org/10.1177/0895904811 417590.

Hooge, E. (1995). Values, increasing autonomy and managing the primary school. In: Paper presented at the AERA, San Francisco, CA.

Hopkins, D. (2001). School improvement for real. London, England: Routledge Falmer.

Hopkins, D., \& Levin, B. (2000). Government policy and school development. School Leadership \& Management, 20(1), 15-30.

Hopkins, D., \& Reynolds, D. (2001). The past, present and future of school improvement: Towards the third age. British Educational Research Journal, 27(4), 459-475.

Hopkins, D., Stringfield, S., Harris, A., Stoll, L., \& Mackay, T. (2014). School and system improvement: A narrative state-of-the-art review. School Effectiveness and School Improvement, 25(2), 257-281. https://doi.org/10.1080/09243453.2014.885452.

House, E. R. (1974). The politics of educational innovation. Berkeley, CA: McCutchan Publishing Corporation.

Imants, J., Zwart, Y., \& Breur, P. (2016). Swinging between two platforms. Accountability policy in the Netherlands and educational leadership in and around schools. In J. Easley II \& P. Tulowitzki (Eds.), Educational accountability international perspectives on challenges and possibilities for school leadership. London, England: Routledge.

Johnson, R. B., Onwuegbuzie, A. J., \& Turner, L. A. (2007). Toward a definition of mixed methods research. Journal of Mixed Methods Research, 1(2), 112-133. https://doi.org/10.1177/15586 89806298224.

Kärkkäinen, K. (2012). Bringing about curriculum innovations: Implicit approaches in the OECD area. OECD Education Working Papers No. 82. Paris: OECD Publishing.

Klein, T., Oomen, C., \& Van der Linden, J. (2008). BBeweging in beeld III, feiten en verhalen over innovatie in het voortgezet onderwijs 2008 [Captured motion III, facts and stories about innovation in secondary education 2008:]. Utrecht, The Netherlands: Council for Secondary Education.

Krüger, M., \& Scheerens, J. (2012). Conceptual perspectives on school leadership. In J. Scheerens (Ed.), School leadership effects revisited. Review and meta-analysis of empirical studies: Springer.

Kyriakides, L., Creemers, B., Antoniou, P., \& Demetrioua, D. (2010). A synthesis of studies searching for school factors: Implications for theory and research. British Educational Research Journal, 36(5), 807-830. https://doi.org/10.1080/01411920903165603.

Kyriakides, L., Creemers, B. P. M., Antoniou, P., Demetriou, D., \& Charalambous, C. Y. (2015). The impact of school policy and stakeholders' actions on student learning: A longitudinal study. Learning and Instruction, 36, 113-124. 
Kyriakides, L., \& Tsangaridou, N. (2008). Towards the development of generic and differentiated models of educational effectiveness: A study on school and teacher effectiveness in physical education. British Educational Research Journal, 34(6), 807-838. https://doi.org/10.1080/014119208020414 67.

Lagerweij, N. A. J. (1987). Theorie van de onderwijsvernieuwing [Theory of educational innovation]. In J. A. Kemenade van, N. A. J. Lagerweij, J. M. G. Leune \& J. M. M. Ritzen (Eds.), Onderwijs: bestel en beleid 3: Onderwijs in ontwikkeling [Education: system en policy 3: Education in the making] (pp. 99-178). Groningen, The Netherlands: Wolters-Noordhoff.

Lagerweij, N. A. J., \& Lagerweij-Voogt, J. (2004). Anders kijken. De dynamiek van een eeuw onderwijsverandering [A different perspective. The dynamics of a century of educational change]. Antwerpen, Belgium: Garant.

Lee, M., \& Hallinger, P. (2012). National contexts influencing principals' time use and allocation: Economic development, societal culture, and educational system. School Effectiveness and School Improvement, 23(4), 461-482. https://doi.org/10.1080/09243453.2012.678862.

Leithwood, K. (2005). Understanding successful principal leadership: Progress on a broken front. Journal of Educational Administration, 43(6), 619-629.

Leithwood, K., Day, C., Sammons, P., Harris, A., \& Hopkins, D. (2006). Successful school leadership. What it is and how it influences pupil learning. Nottingham: University of Nottingham.

Leithwood, K., \& Jantzi, D. (1999). Transformational school leadership effects: A replication. School Effectiveness and School Improvement, 10(4), 451-479.

Leithwood, K., Seashore Louis, K., Anderson, S., \& Wahlstrom, K. (2004). How leadership influences student learning. Review of research. New York, NY: Wallace Foundation.

Leune, J. M. G. (2001). Onderwijs in verandering; reflecties op een dynamische sector [Education in transition; reflections on a dynamic sector.]. Groningen, the Netherlands: Wolters-Noordhoff.

Levacic, R. (2002). Efficiency, equity and autonomy. In T. Bush \& L. Bell (Eds.), The principles and practice of educational management. London, England: Paul Chapman Publishing.

Lidström. (1991). Discretion. An art of the possible. Education committees in the Swedish system of government. Umea: Department of Political Science, University of Umea.

Lubienski, C. (2009). Do quasi-markets foster innovation in education?: A comparative perspective. OECD Education Working Papers, No. 25. https://doi.org/10.1787/221583463325.

Marzano, R. J. (2003). What works in schools: Translating research into action. Alexandria, VA: ASCD.

Marzano, R. J., Waters, T., \& McNulty, B. A. (2005). School leadership that works: From research to results. Alexandria, VA: ASCD.

Maslowski, R., Scheerens, J., \& Luyten, H. (2007). The effect of school autonomy and school internal decentralization on students' reading literacy. School Effectiveness and School Improvement, 18(3), 303-334. https://doi.org/10.1080/09243450601147502.

May, H., Huff, J., \& Goldring, E. (2012). A longitudinal study of principals' activities and student performance. School Effectiveness and School Improvement, 23(4), 417-439. https://doi. org/10.1080/09243453.2012.678866.

Miles, M. B., \& Huberman, A. M. (1994). Qualitative data analysis: an expanded sourcebook (2nd ed.). Thousand Oaks, CA: SAGE Publications.

Mourshed, M., Chijioke, C., \& Barber, M. (2010). How the world's most improved school systems keep getting better. McKinsey \& Company.

Nusche, D., Braun, H., Halász, G., \& Santiago, P. (2014). OECD reviews of evaluation and assessment in education: Netherlands 2014. OECD reviews of evaluation and assessment in education. Paris: OECD Publishing.

OECD. (2011). School autonomy and accountability: Are they related to student performance? Pisa in Focus, $2011(9), 4$.

OECD. (2012). Education at a glance 2012: OECD indicators. OECD Publishing.

OECD. (2013). PISA 2012 results: What makes schools successful? Resources, policies and practices (Volume IV). Paris: OECD Publishing.

OECD. (2014a). Education policy outlook: Netherlands. Paris: OECD Publishing.

OECD. (2014b). Measuring innovation in education: A new perspective. Educational Research and Innovation, OECD Publishing.

OECD. (2014c). Talis 2013 results: An international perspective on teaching and learning. OECD Publishing.

OECD. (2015). Education policy outlook 2015: making reforms happen. Paris: OECD Publishing.

OECD. (2016a). Netherlands 2016: Foundations for the future. Paris: OECD Publishing. 
OECD. (2016b). PISA 2015 results (Volume II): Policies and practices for successful schools. Paris: OECD Publishing.

OECD/Eurostat. (2005). Oslo manual: Guidelines for collecting and interpreting innovation data (3rd ed.). The Measurement of Scientific and Technological Activities, OECD Publishing.

OECD. (undated). Improving school leadership. Policy and practice in OECD countries. Retrieved from http://www.oecd.org/edu/school/44612785.pdf. Accessed 23 Nov 2015.

Paletta, A. (2014). Improving students' learning through school autonomy: Evidence from the international civic and citizenship survey. Journal of School Choice: International Research and Reform, 8(3), 381-409. https://doi.org/10.1080/15582159.2014.942173.

Pont, B., Nusche, D., \& Moorman, H. (2008). Improving school leadership. Volume 1: Policy and practice. Paris: OECD Publishing.

Private Education in the Netherlands. (2015). Particulier Onderwijs Nederland [Private Education in the Netherlands]. Retrieved from http://www.particulieronderwijsnederland.nl/. Accessed 21 Oct 2015.

Regtering, H., \& Van den Broek, A. (2011). Lukt het, loopt het, leert het? Zicht op innovatieprocessen in het basisonderwijs en voortgezet onderwijs [Is it working, is it learning? A persepctive on innovation processes in primary and secondary education]. Nijmegen, The Netherlands: ResearchNed.

Reynolds, D. (2000). An introduction to school effectiveness research. In C. Teddlie \& D. Reynolds (Eds.), The international handbook of school effectiveness research. London, England: Falmer Press.

Reynolds, D., Sammons, P., De Fraine, B., Van Damme, J., Townsend, T., Teddlie, C., et al. (2014). Educational effectiveness research (EER): A state-of-the-art review. School Effectiveness and School Improvement, 25(2), 197-230. https://doi.org/10.1080/09243453.2014.885450.

Reynolds, D., Teddlie, C., Hopkins, D., \& Stringfield, S. (2000). Linking school effectiveness and school improvement. In C. Teddlie \& D. Reynolds (Eds.), The international handbook of school effectiveness research. London, England: Falmer Press.

Robinson, V., Hohepa, M., \& Lloyd, C. (2009). School leadership and student outcomes: Identifying what works and why. Best evidence synthesis iteration (BES). Wellington, New Zealand: Ministry of Education.

Robinson, V., Lloyd, C., \& Rowe, K. (2008). The impact of leadership on student outcomes: An analysis of the differential effects of leadership types. Educational Administration Quarterly, 44(5), $635-674$.

Scheerens, J. (2010). Het innoverend vermogen van de onderwijssector en de rol van de ondersteuningsstructuur. [The innovative power of the educational sector and the role of the support structure]. Paper for the Knowledge Chamber of the Ministry of Education, Culture and Science.

Scheerens, J. (2016). Educational effectiveness and ineffectiveness. A critical review of the knowledge base. Dordrecht, The Netherlands: Springer.

Scheerens, J., \& Steen, R. (2012). Earlier meta-analyses. In J. Scheerens (Ed.), School leadership effects revisited. Review and meta-analysis of empirical studies: Springer.

Schmidt, G. (2009). School leadership: Perceptions and actions. Amsterdam, The Netherlands: University of Amsterdam.

Schmuck, R. A., \& Miles, M. (Eds.). (1971). Organization development in schools. Palo Alto, CA: National Press Books (now Mayfield).

Schmuck, R. A., \& Runkel, P. J. (1985). The handbook of organization development in schools (3rd ed.). Palo Alto, CA: Mayfield.

Seashore Louis, K. (2005). Reconnecting knowledge utilization and school improvement: Two steps forward, one step back. In D. Hopkins (Ed.), The practice and theory of school improvement. International handbook of educational change (pp. 40-61). Dordrecht, The Netherlands: Springer.

Seashore Louis, K., Toole, J., \& Hargreaves, A. (1999). Rethinking school improvement. In J. Murphy \& K. Seashore Louis (Eds.), Handbook of research on educational administration (2nd ed.). San Francisco, CA: Jossey-Bass Publishers.

Shirley, D. (2016). How to lead educational change. Journal of Educational Change, 17(3), 281-285. https://doi.org/10.1007/s10833-016-9281-9.

Slavin, R. E. (2005). Sand, bricks, and seeds: School change strategies and readiness for reform. In D. Hopkins (Ed.), The practice and theory of school improvement. International handbook of educational change (pp. 265-279). Dordrecht, The Netherlands: Springer.

Smith, K. N. (2011). Decision making under multiple accountability policies: A study of genesee county's high school leaders. Michigan State University. 
Spillane, J. P., \& Lee, L. C. (2014). Novice school principals' sense of ultimate responsibility: Problems of practice in transitioning to the principal's office. Educational Administration Quarterly, 50(3), 431-465. https://doi.org/10.1177/0013161X13505290.

Stamos. (2015). Employment in Dutch Secondary Education. Retrieved from http://www.stamos.nl/ index.rfx?verb=showitem\&item $=5.2$.

Steinberg, M. P. (2012). Does greater autonomy improve school performance? Evidence from a regression discontinuity analysis in Chicago. Education Finance and Policy, 9(1), 1-35. https://doi. org/10.1162/EDFP_a_00118.

Tashakkori, A., \& Teddlie, C. (1998). Combining qualitative and quantitative approaches. Thousand Oaks, CA: Sage Publications.

Theisens, H., Hooge, E., \& Waslander, S. (2017). How exceptional are the Dutch? Identifying general and country specific characteristics of governance in multi-layered polycentric education systems. In: Paper presented at the 2017 AERA Annual Meeting, San Antonio, TX.

Townsend, T., \& MacBeath, J. (Eds.). (2011). International handbook of leadership for learning (Vol. 25). Springer.

Triant, B. (2001). Autonomy and innovation: How do Massachusetts charter school principals use their freedom?. Washington, DC: Thomas B. Fordham Foundation.

UNESCO Education Sector. (2016). Leading better learning: School leadership and quality in the Education 2030 agenda. Regional reviews of policies and practices: Division for Policies and Lifelong Learning Systems (ED/PLS), Section of Education Policy (ED/PLS/EDP).

Verbiest, E. (2011). Leren Innoveren. Een inleiding in de onderwijsinnovatie [Learn to innovate. An introduction into educational innovation]. Antwerp, Belgium: Garant.

Verschuren, D. (2013). Het geheim van de innovatieve schoolleider [The secret of the innovative school leader]. Hertogenbosch: KPC Groep.

Vieluf, S., Kaplan, D., Klieme, E., \& Bayer, S. (2012). Teaching practices and pedagogical innovation: Evidence from TALIS. Paris: OECD Publishing.

Vodegel, F., Van den Bosch, H., \& Smid, G. (2015). Integraal perspectief op onderwijsinnovatie. [Integral perspective on educational innovation]. OnderwijsInnovatie [EducationalInnovation], 2, 34-39.

Waslander, S. (2007). Leren over innoveren. Overzichtsstudie van wetenschappelijk onderzoek naar duurzaam vernieuwen in het voortgezet onderwijs. [Learning about innovation. A review on scientific research on sustainable innovation in secondary education]. Utrecht, The Netherlands: Council for Secondary Education.

Waslander, S. (2010). Government, school autonomy, and legitimacy: Why the Dutch government is adopting an unprecedented level of interference with independent schools. Journal of School Choice, 4(4), 398-417. https://doi.org/10.1080/15582159.2010.526845.

Werfhorst, H. G. V. D., \& Mijs, J. J. B. (2010). Achievement inequality and the institutional structure of educational systems: A comparative perspective. Annual Review of Sociology, 36, 407-428. https:// doi.org/10.1146/annurev.soc.012809.102538.

Whitty, G. (1997). Creating quasi-markets in education: A review of recent research on parental choice and school autonomy in three countries. Review of Research in Education, 22(1), 3-47.

Wildy, H., Forster, P., Louden, W., \& Wallace, J. (2004). The international study of leadership in education: Monitoring decision making by school leaders. Journal of Educational Administration, 42(4), $416-430$.

Woessmann, L., Luedemann, E., Schuetz, G., \& West, M. R. (2009). School accountability, autonomy and choice around the world. Northampton, MA: Edward Elgar.

Wohlstetter, P., Wenning, R., \& Briggs, K. L. (1995). Charter schools in the United States: The question of autonomy. Educational Policy, 9(4), 331-358. https://doi.org/10.1177/0895904895009004001.

Wonderen, R. V. (2004). Innovatie in het primair onderwijs. Eindrapport [Innovation in primary education. Final report.]. Leiden, The Netherlands: Research voor beleid [Research for policy].

Wrigley, T. (2008). School improvement in a neo-liberal world. Journal of Educational Administration and History, 40(2), 129-148. https://doi.org/10.1080/00220620802210905.

Wrigley, T. (2011). Paradigms of school change. Management in Education, 25(2), 62-66. https://doi. org/10.1177/0892020611398929.

You, Y., \& Morris, P. (2016). Imagining school autonomy in high-performing education systems: East Asia as a source of policy referencing in England. Compare: A Journal of Comparative and International Education, 46(6), 882. https://doi.org/10.1080/03057925.2015.1080115. 